\title{
. \\ Stolen Wages, Corruption, and Selective Application of the Law: Is APUNCAC a Solution?
}

\author{
Anna Notley ${ }^{1, *}$ and Bob Hodge ${ }^{2, *}$ \\ 1 School of Law and Criminology, Murdoch University, Murdoch, WA 6150, Australia \\ 2 Institute of Culture and Society, Western Sydney University, Parramatta, NSW 2150, Australia \\ * Correspondence: annahvnotley@gmail.com (A.N.); b.hodge@westernsydney.edu.au (B.H.)
}

Citation: Notley, Anna, and Bob Hodge. 2022. Stolen Wages,

Corruption, and Selective

Application of the Law: Is

APUNCAC a Solution? Laws 11: 18.

https://doi.org/10.3390/

laws11020018

Received: 12 December 2021

Accepted: 24 February 2022

Published: 3 March 2022

Publisher's Note: MDPI stays neutral with regard to jurisdictional claims in published maps and institutional affiliations.

Copyright: () 2022 by the authors Licensee MDPI, Basel, Switzerland. This article is an open access article distributed under the terms and conditions of the Creative Commons Attribution (CC BY) license (https:// creativecommons.org/licenses/by/ $4.0 /)$.

\begin{abstract}
APUNCAC is a draft international convention designed to address systemic corruption, strengthening UNCAC's provisions and adding mechanisms to make it more effective. 'Corruption' includes public officials abusing their powers. This article addresses an especially insidious form: when laws are created and applied to deny equal protection under the law. Ruling elites control the executive and parliament, to pass laws that selectively target and disadvantage a segment of the population. Our empirical data comes from a historical case, massive government-sanctioned wage theft from Western Australian Aboriginal workers between 1901 and 1972. We use these data to analyse how this kind of corruption works in practice, to evaluate APUNCAC's measures and strategies, to see what specific measures might be used or modified, and where APUNCAC might need supplementing. We argue that Article 4(3) could have a major impact, especially supported by other Articles and processes, such as dedicated independent courts and strategic engagement with local courts. We evaluate two scenarios: The first scenario is prospective, assuming that APUNCAC is adopted. We evaluate the possible impact of APUNCAC in deterring future corruption involving selective application of the law. The second scenario is retrospective. We evaluate the possible support that APUNCAC might provide regarding court actions that seek redress for potential litigants, such as WA Aboriginal people who were injured in the past.
\end{abstract}

Keywords: APUNCAC; anticorruption instruments; stolen wages; systemic corruption; rule of law; equality before the law

\section{Introduction}

An especially insidious form of corruption occurs when laws are created and applied in ways that deny equal protection under the law, where ruling elites use their control over the executive, legislature, and judiciary to pass laws and preside over processes that selectively target and disadvantage a segment of society. An example of this type of corruption occurred during a period of Australian history when Aboriginal people were almost uniformly subjected to inhumane conditions by the Australian government. From the mid-19th century until at least the 1960s, Aboriginal people were dispossessed and subjected to conditions described as akin to slavery by Sir Paul Hasluck (1970), later to be Australian Governor-General (see also Auty 2000). Vulnerable people were coerced into accepting what modern observers might consider intolerable conditions. Police were authorized to control where Aboriginal people could live. Many Aboriginal people were confined to reserves, liable to be arrested if they sought to leave authorized employers. Under these circumstances, Aboriginal workers accepted deals where they never received the promised wages, only food, or lodgings for themselves or their families, in locations they were compelled to live. In sum, the 'stolen wages' case refers to an episode in Western Australian (WA) history between 1901 and 1972, when USD 22 billion were allegedly appropriated corruptly from Aboriginal workers by the WA government by withholding wages, claiming to hold them in escrow for the workers' benefit but never returning 
them (Senate Standing Committees on Legal and Constitutional Affairs 2006). Aboriginal workers were denied equal protection by laws against wage theft.

This article contributes to the aims of this Special Issue by evaluating a specific strategy for tackling this type of corruption. The strategy involves the implementation of a model international convention. The Anticorruption Protocol to the United Nations Convention against Corruption (APUNCAC) is a draft international treaty that aims to strengthen the existing United Nations Convention Against Corruption (UNCAC), by establishing an enhanced legal framework and enabling strong, aggressive action (Yeh 2021). APUNCAC would implement an equal protection clause and would provide recourse, in the form of class actions, in cases where public officials abuse their powers, create and implement laws that deny equal protection under the law, and selectively disadvantage a segment of society.

The purpose of this article is to evaluate the APUNCAC strategy and assess its utility for addressing corruption involving unequal application of the law. The approach involves analysis of the WA stolen wages case, analysis of the application of APUNCAC to this case, and assessment of the utility of the APUNCAC strategy in addressing injustice that occurs when those in power abuse their power to selectively disadvantage disfavored segments of society.

We evaluate two scenarios: The first scenario is prospective, assuming that APUNCAC is adopted. We evaluate the possible impact of APUNCAC in deterring future corruption involving selective application of the law. Adoption of APUNCAC would ensure the existence of a remedy for future instances of the type of crime that is illustrated by the WA stolen wages case and would send a clear signal that selective targeting of a segment of society is not acceptable. The second scenario is retrospective. We evaluate the possible support that APUNCAC might provide regarding court actions that seek redress for potential litigants, such as WA Aboriginal people, who were injured in the past.

One potential outcome of our analysis would be a change in laws, to prevent this kind of corruption ever happening again in this jurisdiction. That would be desirable, but is not enough for our litigants. This leaves us with a difficult challenge, which we nonetheless take up: is there a way these Aboriginal litigants could use and adapt APUNCAC for court action in the present, given that the disadvantages they suffered continue so strongly into the present? An APUNCAC approach turns reprehensible behaviors into crimes examined by courts and punishable by law. We argue from our analysis, that APUNCAC could be developed to become a game-changer for these litigants.

Section 2 of this article describes and analyzes the WA stolen wages case. Section 3 analyzes key APUNCAC articles. We begin with 4(3). We argue it plays a crucial role in making APUNCAC an important extension of the anticorruption toolkit. We look at how it is embedded in APUNCAC strategies. We examine Article 4(1)(c) on abuse of authority, and show its valuable role in supporting 4(3). We then summarize answers to the crucial question: Why APUNCAC? In response to this question, we synthesize other articles that could come into play to strengthen the case, including Article 7 on access to the process, Article 8 on dedicated courts, Article 10 on implementation of court findings, and Articles 60, 62, and 63 dealing with sanctions that can be applied to proven offences. These discussions contribute to the main aim of the article, to use examples from our empirical case to analyze and evaluate APUNCAC. We consider this in two scenarios: as a general strategy to bring difficult dimensions of corruption within the framework of international regulation; and as a proposed legal instrument designed to 'make a difference', in Annan's terms, to issues of world governance and the management of corruption. Section 4 assesses the utility of the APUNCAC strategy in addressing the type of injustice illustrated by the WA stolen wages case.

\section{The 'WA Stolen Wages' Case}

The (WA Government 1905) WA forbade Aboriginal workers to be paid directly, instead requiring employers to pay these funds into a state-managed trust fund, supposedly 
on the workers' behalf. These funds were never paid to Aboriginal workers. In 2006, an Australian government inquiry into the matter stated:

There is compelling evidence that governments systematically withheld and mismanaged Indigenous wages and entitlements over decades. In addition, there is evidence of Indigenous people being underpaid or not paid at all for their work. These practices were implemented from the late 19th century onwards and in some case were still in place in the 1980s. Indigenous people have been seriously disadvantaged by these practices across generations. (Senate Standing Committees on Legal and Constitutional Affairs 2006, p. 4)

Table 1 combines official census data (ABS 1966) with data from the FWC Australia (2021) and academic researcher Charles Rowley (1970), to estimate the amount of damages, equal to USD 22.2 billion, using conservative figures. A more complete forensic analysis would presumably support a higher figure. However, the conservative USD 22 billion figure establishes the magnitude of the corruption.

Table 1. Aboriginal Wages Due and Appropriated.

\begin{tabular}{ll}
\hline \multicolumn{2}{c}{ Assumptions } \\
\hline A. Aboriginal workers (aged 15-65) per year & 11,247 (ABS 1966) \\
B. Time frame (1905-1972) Gov-managed wages & 67 years \\
C. Minimum wage (FWC Australia 2021) & USD 29,474 per year \\
D. Total wages earned/appropriated $(A \times B \times C)$ & USD 22.2 billion \\
\hline
\end{tabular}

The report produced by the inquiry failed to properly establish the scale of the alleged theft, failed to properly acknowledge the associated corruption, and failed to propose legislative or political remedies. The Inquiry acknowledged that essential records were not produced, were lost, or were destroyed (Senate Standing Committees on Legal and Constitutional Affairs 2006, p. 5; see also Kidd 2007).

In 2012, six years after the Senate Inquiry, the WA government established a 'redress' scheme involving nominal ex gratia payments of USD 1460 per person, so that the state government could 'express regret' to Aboriginal people still living who had resided at government Native Welfare Settlements and had monies withheld. The redress scheme appeared to show that Australian governments now accept guilt and responsibility, suggesting that the case was strong. However, numerous limitations were built into the terms of reference. There was a 6-month window in which to apply, so many eligible people failed to receive payment. Other barriers included the detail required, despite the culpably inadequate book-keeping, which essentially served as a strategy to ensure that as few claimants as possible could access any funds, despite the claimed intent of the scheme to 'provide redress'.

Subsequent class action cases suggest the nominal nature of these payments. In 2020, Shine Lawyers, a commercial law firm, won a class action judgement of USD 139.4 million in a stolen wages case in Queensland. Their success inspired a similar class action in WA, which is currently underway. The Queensland case demonstrates the feasibility and power of civil actions. The payout was 76 times the WA government redress payout. However, documentation was difficult or, in most cases, impossible to obtain, owing to what the Senate Inquiry had described as negligence or corruption. Payouts to claimants were not timely nor sufficient, and the corruption dimension was not examined.

\section{APUNCAC}

APUNCAC Article 4(3) would establish, for nationals of all States Parties, equal protection under the law:

States Parties to the Protocol shall not make or enforce any law which shall abridge the privileges or immunities of citizens of the States Parties; nor shall any State Party deprive any person of life, liberty, or property, without due process 
of law; nor deny to any person within its jurisdiction the equal protection of the laws.

Under APUNCAC, it would not have been legal to misappropriate Aboriginal worker wages. Furthermore, under APUNCAC Article 60(6), it would have been unlawful for the WA government to benefit from stolen Aboriginal wages:

It is unlawful for any person or entity to initiate, facilitate, or benefit from a pattern of corruption, misappropriation of assets or any other form of racketeering activity, if the accused knew or should have known of the corruption, the asset misappropriation or other form of racketeering activity. (APUNCAC art. 60(6))

Under APUNCAC Article 60(4), it would have been unlawful for the WA government to receive the proceeds of misappropriated Aboriginal worker wages:

It is unlawful for any person or entity to handle, receive, hold, transfer or convey assets that the accused knew, or should have known, were obtained through a pattern of corruption, misappropriation of assets or any other form of racketeering activity, with the exception of entities duly authorized by criminal investigators for the purpose of facilitating criminal investigations, or entities duly authorized for the purpose of imposing a lien or facilitating a civil action under this Protocol.

\subsection{Class Actions}

Under APUNCAC Articles 62(6) and 63(5), a class action could be initiated that would permit a nongovernmental organization such as the International Justice Mission (IJM) to bring a class action on behalf of Aboriginal workers who were deprived of their wages as a consequence of WA government action and seek treble damages. ${ }^{1}$ One merit of this recourse is that it bypasses the State Party's close control of legal processes within its jurisdiction, by referring implementation out to another international body. However, State Party support would still be needed, to ensure this massive payout happened. In sum, APUNCAC's equal protection clause could be used in the first stage, in a process to seek redress and return such stolen wages.

We argue that a compelling case against this kind of corruption, illustrated by the stolen wages case, could be built by applying APUNCAC. Australia is a State Party to the Vienna Convention on the Law of Treaties. The Vienna Convention requires each State Party to a treaty to conform domestic law to treaty commitments. ${ }^{2}$ This situation should encourage potential litigants to look to APUNCAC for possible relief. Our initial forensic investigation is well within the capacity of a small dedicated legal team who could support this action. Our initial analysis showed that class action is possible, though on a limited scale. We estimated a claim of USD 22 billion. If we factor in the possible option of a class action under Articles 60(6) and 63(5), which allows claims up to three times the amount claimed, then the potential figure becomes USD 66 billion. This is 480 times the Queensland figure. These figures are only estimates, but they show the comparative scale and possible impact of a potential APUNCAC case.

In this first pass at evaluating APUNCAC, it offers attractive options to potential litigants, in a court as envisaged under Article 8. We see this outcome as worthwhile. Under no other circumstances could this type of litigant get their day in court, backed by international resources and international prestige.

However, this is not the end of the story for an evaluation of APUNCAC's real-world impact. Resistance can be expected from affected State Parties, and this expectation is built into APUNCAC's provisions and strategies for addressing the possibility that domestic authorities might fail to cooperate or might engage in obstruction of justice (see Yeh 2015).

1 We wish to express our gratitude to Professor Stuart Yeh here as editor for this special issue for comments and suggestions during the writing of this article. We are of course ultimately responsible for its final form.

2 Vienna Convention on the Law of Treaties (opened for signature 23 May 1969, entered into force 27 January 1980) Art. 27, 1155 UNTS 331 ("A party may not invoke the provisions of its internal law as justification for its failure to perform a treaty"). 
APUNCAC's provisions for independent international inspectors, independent agencies to monitor treaty implementation, and provisions to censure acts of noncooperation or obstruction of justice arguably address a basic weakness in UNCAC, its reliance on domestic authorities for implementation and the constrained capacity of external agencies to monitor and control domestic implementation (Webb 2005; Brunelle-Quraishi 2011). Heckler (2010, p. 6) noted the same weakness in UNCAC and its limited powers of coercion: 'Ratification of the UNCAC does not constitute political will in itself'. Compliance is a major problem for UNCAC, but accommodation is built in. As Heckler (2010, p. 1) noted: 'Most provisions of the Convention make some reference to working within a State's domestic Law, which allows significant room for different interpretations of the Convention's requirements'.

APUNCAC envisages a process that may be pursued by aggrieved litigants. We interpret Article $7(2)(\mathrm{d})$ as implying that potential litigants should be able to provide evidence on how the case would fare in State Party courts. This requirement recognizes a basic fact about APUNCAC that legal teams seeking to support marginalized litigants like ours will be aware of from the outset. APUNCAC processes rely on the hard work these lawyers must commit to, to carry the whole process through to a successful intervention. APUNCAC does not expand on this point, and it does not fall within its brief to do so. However, it is part of the real-world context that will determine whether any given intervention succeeds or fails.

\subsection{Retrospectivity}

The Stolen Wages case is situated in the uncertain space between the ideal scope of an APUNCAC based on principles of the rule of law, and a real world where many State Parties are 'kleptocracies' (Burgis 2020), flagrantly corrupt while pretending otherwise. The principle of equality before the law, articulated in Article 4(3), conflicts with kleptocratic practices that are diametrically opposed to equal protection under the law.

In this regard, Kaufmann and Vicente's ideas (2011) are helpful. They argue that extreme corruption is normally enabled by two main ways of departing from the rule of law. 'Illegal corruption' is rampant impunity, where laws are systematically broken by corrupt elites. They call the other main kind of corruption 'legal corruption', where governments and judiciaries create and apply special laws to enable their corruption. These strategies in practice form a single package. Both potentially present massive challenges to the acceptance and implementation of APUNCAC.

The Stolen Wages case highlights these issues in their theoretical and real-life complexity. The first problem concerns the place of APUNCAC laws in State Party systems. Laws like 4(3) based on principles of the Rule of Law are more likely to be compatible with State Party laws for that reason. If equal protection is enshrined deep in State Party systems, as famously in the case of the American Constitution and others influenced by it, this will pave the way for this kind of case.

However, it is not clear what Australian law says about equal protection. The Australian Constitution does not explicitly provide for equal protection. Australia has no Bill of Rights, nor has the High Court been willing to accept many implied rights in the Constitution (Libesman 2019). In State Parties such as Australia that lack an equal protection clause, we argue that Article 4(3) would tend to promote the rule of law. However, until that case is argued successfully up to the High Court, the principle would have to be argued in relation to the case, and the Australian Constitution would have to be subjected to high-level scrutiny. Our initial legal team would need support from high-level legal counsel. We believe, in so high profile a case as this, that help would be available, in Australia as in equivalent jurisdictions.

In its original form, assented to in 1900, section 127 of the Australian Constitution stated: 'In reckoning the numbers of the people of the Commonwealth, or of a State or other part of the Commonwealth, aboriginal natives should not be counted' (Australian Constitution n.d., §127). A referendum in 1967 resulted in removing section 127 and the 
words "other than the aboriginal people in any state," from section 51 on the powers of the Commonwealth:

The Parliament shall, subject to this constitution, have power to make laws for the peace, order and good government with respect to:

(xxvi) the people of any race for whom it is necessary to make special laws (Australian Constitution n.d., §51).

Before these amendments were made it could be argued that racism against Aboriginal people was permitted by the Constitution. If so, it could be argued that APUNCAC Article 4(3) would have been unconstitutional, but is now compatible with Australian law. The phrase crossed out was deleted, implying that, after the amendment, specific discrimination against Aboriginal people was prohibited. That would ease the way for 4(3) to be incorporated into Australian law, able to be appealed to in an APUNCAC case, able to be appealed to, but only after 1967.

However, the wording of the excessively simple amendment leaves another interpretation still on the table. The statement about powers is reminiscent of language of the rule of law. This is no accident, because the framers of the Constitution were conscious of their high duty. It could be argued that a principle like Article 4(3) was always relevant and could always have been used to declare the relevant laws unconstitutional and, hence, invalid. That is, retrospectivity is not an issue, before or after 1967 .

\subsection{Corruption as Abuse of Authority-Article 4(1)(c)}

A complementary argument could be put in this case and others like it. The WA Government had the backing of inadequate laws (legal corruption), they also operated outside those laws with impunity (illegal corruption). This new argument would draw on APUNCAC Article 4(1)(c) to strengthen the basis for Aboriginal litigants to seek redress for stolen wages. Article 4(1)(c) focuses on abuse of authority. It states that corruption includes:

Any act or omission in the discharge of his or her duties by a public official or any other person for the purpose of illicitly obtaining benefits for himself or for another party.

The Senate Standing Committees on Legal and Constitutional Affairs (2006) provided abundant evidence of systemic abuse of authority by the police and other officials who were delegated responsibility. The facts are not in dispute. However, the case needs to be made that this was not laziness or incompetence, the benign interpretation usually given by reports such as the Senate Inquiry, but culpable corruption in terms of 4(1)(c). First, the authority given under the law is conditioned by its aim, 'to protect (aborigines) from injustice, imposition and fraud'. There has been no change in English that would turn 'protect from' into 'commit on a large scale'. Nor has there been change in the key term 'fraud'. On the contrary, it was extensively defined in the WA Government's (1904) Audit Act. With the Commissioner's powers conferred mostly to police officers as Public Accountants, these officers were bound under The Audit Act 1904 (WA) s17 by the provisions and regulations in this Act.

In our case, there are strategic advantages coming from using these two articles in tandem, especially where there is evidence of corruption of laws and processes in the two forms identified by Kaufmann and Vicente (2011). 'Legal corruption' in this case would be targeted by arguing that the WA Government's Aborigines Act 1905 was 'bad law' to such an extent that it betrayed the legislative function and should have been struck down from the outset. 'Illegal corruption' captures the systematic impunity exercised by corrupt elites. This clearly occurred on such a scale in this case that it would support an adverse finding on this aspect alone and damage an argument of good faith in the whole case.

One merit of an argument using Article 4(1)(c) in this case is that it helps blunt a likely State Party defense, that if the laws were legal at the time, or if they conformed to contemporary beliefs, then those who acted legally or in good faith in those terms cannot be 
held liable. According to this argument, Aboriginal people were not even citizens then, and had no rights to protect them. Our counterargument is that bad laws offer less protection for that defense.

From our experience, in this case mediated by Kaufmann and Vicente's more general analysis of extreme corruption, we offer a rule of thumb for others confronted by illegal or legal corruption. Laws designed to further corruption are likely, a fortiori, to be bad laws, more open to challenge than most, and will typically be administered corruptly. The key legitimating Act in this case was demonstrably flawed, compared to other laws passed by the same legislature, open to a strong attack from any later period.

This motivates a viable version of our case under APUNCAC that does not fall foul of the principle against retrospectivity. Article 4(1)(c), in combination with Article 4(3), makes it unlawful for WA government authorities, then as now, to selectively apply the law in a way that misappropriates the wages of Aboriginal workers for the benefit of the WA government. Articles 60(4), 60(6), 62(6), and 63(5) would permit an NGO such as IJM (2021) to file a class action on behalf of Aboriginal workers (or their heirs) to seek treble damages. Article 60(6) makes it unlawful for the WA government to receive stolen wages. Article 60(6) makes it unlawful for the WA government to benefit from stolen wages. Article 63(5) permits an NGO to file a class action. Article 62(6) permits an NGO to seek treble damages.

Without the APUNCAC option, these litigants would face a difficult task. Australia's existing legal framework has resulted in a mixed record regarding abuse of authority cases. Terri Libesman (2019) reviewed judicial responses to a high-profile Australian Human Rights Commission (1997) inquiry on the 'Stolen Generations', which investigated another policy legitimated primarily by the same laws; the WA Government's Aborigines Act 1905 and similar laws in other state jurisdictions that involved taking Aboriginal children from their Aboriginal families, ostensibly for their welfare, but in practice purely because of their Aboriginality. This inquiry found a similarly scandalous dereliction of the State's duty of care and of its agents regarding Aboriginal children and families. However, individual cases demanding compensation for demonstrated breach of the duty of care by state officials were mostly unsuccessful.

This mixed record indicates the difficulty of sustaining a charge of abuse of authority under current law. In one Stolen Generations case, Justice O'Loughlin acknowledged that the State had a duty of care regarding the Aboriginal plaintiff, but ruled that it had not been breached sufficiently (Libesman 2019, p. 37). In another case, however, Justice Gray sustained a claim of abuse of authority, stating that the claimant was dealt with by the State without lawful authority (Libesman 2019, p. 39). These cases suggest that abuse of authority claims can currently be argued in Australian courts, even for historical cases, but outcomes are uncertain. Ratification of APUNCAC could potentially open the door to more aggressive legal action.

In summary, the analysis suggests (a) the WA government selectively withheld wages from Aboriginal workers but not other workers; (b) that they did so corruptly, by corrupt means and without lawful authority; and (c) APUNCAC would allow a case to go to the domestic courts, addressing the fundamental issues, and permit an NGO to file a class action seeking treble damages. APUNCAC opens avenues for redress that were not previously available. Rulings of an APUNCAC court would not absolutely bind subsequent legal processes in State Party courts, but it cannot be doubted that they would have massive impact, far more than these litigants and their supporters could hope to achieve by any other means

\section{Assessment and Conclusions}

In this final section we review the arguments thus far by taking a hard look at APUNCAC from the point of view of prospective Aboriginal litigants. How would they evaluate it? What would it offer them? How might they use and adapt it to their purposes? How could the core theme of equality before the law assist them in combating the corruption they suffered? 
APUNCAC is a draft international treaty. That might seem to make it too weak to be of real benefit to potential litigants. Treaties are voluntary. Signature and ratification are voluntary. They work to the extent that States Parties agree to abide by these voluntary agreements. However, we would argue strongly to these marginalized citizens to see their great potential value. The proliferation of international agreements, and the broad willingness of UN Member States to sign, ratify, and abide by such agreements, signals their value. States Parties are persuaded that it is beneficial to sign, ratify, and abide by such agreements, as Australia has regularly done (see Sidoti 2011; Kenny and Fiske 2014; Harris 2015). In short, they work because of the soft-power and persuasion exerted by other parties and the international community. Miguel de Serpa Soares (2019), UN Legal Counsel, made strong claims about this type of soft-power strategy:

The Vienna Convention on the Law of Treaties has had a fundamental role in the history of international relations and unrivalled importance as a source of international law, as well as a means of developing peaceful co-operation among nations (2019).

UN conventions influence State Party laws by affecting international and, hence, national laws and rule of law institutions. APUNCAC, as a convention, would require parties to work together by agreement, appealing to the rule of law. Vulnerable parties and their allies could use APUNCAC to mobilize their own soft power.

One potential benefit is Article 7(1), which permits any individual to submit a charge of corruption. Corrupt elites are typically wealthy, privileged, and powerful; their wealth perpetuated by corruption. Victims of corruption are likely to be poor and marginalized, socially, economically, and legally, as are most Aboriginal people. As Wayne Martin, former Chief Justice of the WA Supreme Court said (Martin 2017), most Aboriginal people live below the poverty line, the most marginalized group in Australian society. They mostly rely on hard-pressed, underfunded Aboriginal Legal Services in each state.

Article 7(1) addresses the fact that most Aboriginal litigants are de facto excluded from full access to the law. Aboriginal attempts to seek redress were often hampered by issues of standing (Berhendt et al. 2019). Most Aboriginal people could hardly imagine taking matters to any court without pro bono legal representation. Costs alone would be unsurmountable barriers, with further threats of costs being awarded against them. Article 7(1) potentially opens doors for individuals who previously had no recourse.

Article 7(10)(e) is another small article which could have very great positive consequences. Article 7(10) describes a proposed 15-member Operations Review Committee. Article 7(10)(e) states that this committee can provide 'recommendations as needed regarding changes in domestic laws, institutions or governance which would reduce opportunities for corruption.' The case as we have argued it could use this process. This would benefit the plaintiffs, who otherwise would not be heard at this level. At the same time international bodies committed to opposing corruption would welcome a victory of this kind at this level. Victory would not be guaranteed, but this would be more favorable terrain on which to wage the struggle. As we have seen, APUNCAC could support a strong case using Articles 4(3) and Article 4(1)(c), facilitated by the independence of the proposed APUNCAC inspectors and courts as under Article 8. This in turn would provide the basis to file a class action to recover treble damages, USD 66.6 billion in the stolen wages case, using Articles 62(6) and 63(5) as we have described. A successful case on this scale would have international ramifications. The prospect of large damages would affect future calculations of government officials. For marginalized litigants and victims of systemic corruption facing the otherwise overwhelming power of corrupt actors in unjust, corrupt states, APUNCAC could make a decisive difference.

We have found many reasons to admire APUNCAC, reasons that carry insights into issues, problems, and strategies in the international governance of corruption. Those insights are our main contribution to this special issue. We believe that APUNCAC would demonstrably strengthen UNCAC. At the same time and more surprisingly it could be a game-changer for our putative Indigenous litigants. It uses the framework of corruption to 
prosecute injustices against them as crimes, specified and prosecuted under the law, in the spirit of the rule of law, rather than as moral blemishes for which later populations and governments should feel shame. Unfortunately, shame has proven an insufficient motive for real change (Pedersen et al. 2004).

APUNCAC has many measures that would make the aspirations of UNCAC more effective. At the same time, we need to keep a judicious perspective, and not overstate the power of such instruments to achieve total justice. We remember Kofi Annan's wise words in the foreword to the original UNCAC. He hoped that it would 'make a real difference to the quality of life of millions of people around the world' (United Nations 2004, p. iv). At the same time, he acknowledged the scale of the challenges, so that the best he could hope was that 'together, we can make a difference'. UNCAC did make a difference, and that difference allowed APUNCAC to be proposed to make another difference. The world needs judicious hope and effective strategies, and that is what APUNCAC offers.

Author Contributions: All authors contributed equally to conceptualization; methodology; analysis; investigation; writing: original draft, revision, and editing. All authors have read and agreed to the published version of the manuscript.

Funding: This research received no external funding.

Institutional Review Board Statement: Not applicable.

Informed Consent Statement: Not applicable.

Data Availability Statement: Not applicable.

Conflicts of Interest: The authors declare no conflict of interest.

\section{References}

Australian Constitution. n.d. Commonwealth of Australia Constitution Act 1900 UK; Canberra: Australian Government.

Australian Bureau of Statistics (ABS). 1966. Available online: www.abs.gov.au (accessed on 30 June 2021).

Auty, Kate. 2000. Western Australian courts on Native Affairs 1936-1954-One of 'our' little secrets in the administration of 'justice' for Aboriginal people. UNSW Law Journal 23: 149.

Berhendt, Larissa, Chris Cuneen, Terri Libesman, and Nicole Watson. 2019. Aboriginal and Torres Strait Islander Legal Relations, 2nd ed. Melbourne: Oxford University Press.

Brunelle-Quraishi, Ophélie. 2011. Assessing the relevance and efficacy of the United Nations Convention Against Corruption: A comparative analysis. Notre Dame Journal of International and Comparative Law 2: 101-66.

Burgis, Tom. 2020. Kleptopia. New York: HarperCollins.

de Serpa Soares, Miguel. 2019. Speeches. Geneva: Office of UN Directory of Legal Affairs.

Fair Work Commission of Australia. 2021. Available online: www.fwc.gov.au (accessed on 23 July 2021).

Harris, Bede. 2015. Constitutional Law Guidebook. Oxford: Oxford University Press.

Hasluck, Paul. 1970. Black Australians: A Survey of Native Policy in Western Australia 1829-1897, 2nd ed. Carlton: Melbourne University Press.

Heckler, Hannes. 2010. UNCAC in a Nutshell. Bergen: U4 Anticorruption Resource Centre.

International Justice Mission Australia (IJM). 2021. Available online: www.ijm.org.au (accessed on 12 October 2021).

Kaufmann, Daniel, and Pablo Vicente. 2011. Legal corruption. Economics and Politics 23: 195-219. [CrossRef]

Kenny, Mary Anne, and Lucy Fiske. 2014. Social Work in the Shadow of the Law. Sydney: Federation Press.

Kidd, Ros. 2007. Hard Labour, Stolen Wages: National Report on Stolen Wages. Strawberry Hills: Australians for Native Title and Reconciliation (ANTaR).

Libesman, Terri. 2019. Warfare to Welfare: Genocide to racial discrimination. In Aboriginal and Torres Strait Islander Legal Relations, 2nd ed. Edited by Larissa Berhendt, Chris Cuneen, Terri Libesman and Nicole Watson. Melbourne: Oxford University Press.

Martin, Wayne. 2017. Unequal Justice for Indigenous Australians. Darwin: Criminal Lawyers' Association of the Northern Territory Biennial Conference.

Pedersen, Anne, Jaimie Beven, Iain Walker, and Brian Griffiths. 2004. Attitudes toward Indigenous Australians: The role of empathy and guilt. Journal of Community \& Applied Social Psychology 14: 233-49.

Rowley, Charles. 1970. The Destruction of Aboriginal Society. Canberra: ANU Press.

Senate Standing Committees on Legal and Constitutional Affairs. 2006. Unfinished Business: Indigenous Stolen Wages; Canberra: Australian Government.

Sidoti, Chris. 2011. National human rights institutions and the International human rights system. In Human Rights Compliance and Social Change. Edited by Ryan Goodman and Thomas Pegram. Cambridge: Cambridge University Press. 
Australian Human Rights Commission. 1997. Bringing Them Home Report 1997. Sydney: Australian Human Rights Commission. United Nations. 2004. United Nations Convention against Corruption. Geneva: United Nations.

WA Government. 1904. Audit Act 1904 (WA); Perth: WA Government.

WA Government. 1905. Aborigines Act 1905 (WA); Perth: WA Government.

Webb, Philippa. 2005. The United Nations Convention Against Corruption: Global achievement or missed opportunity? Journal of International Economy and Law 8: 191-229. [CrossRef]

Yeh, Stuart. 2015. Why UN Inspections? Corruption, Accountability and the Rule of Law. South Carolina Journal of International Business and Law 11: 227-60.

Yeh, Stuart. 2021. Anticorruption Protocol to the United Nations Convention against Corruption. Available online: http://tinyurl. com/y6bkpott (accessed on 30 May 2021). 